scale are not fully exploited. An important aspect of the Global Stratotype Points (GSP) is that they represent reference points where both geological time and rock are defined. Traditionally, geological history has been perceived in two ways, one rock-related and one time-related. This is manifested in the conventional twosplit stratigraphic (time) scale where chronostratigraphical units (system, series, stage) are matched against geochronological units (period, epoch, age). One principal reason why this divided perception originally evolved, were the uncertainties in correlation that arouse because (immaterial) time boundaries were not satisfactorily defined in relation to (material) rock boundaries. The GSP represents the base of a rock unit as well as the beginning of a time unit, which both continue up to the next GSP, and the conventional, divided perception of Earth history will be of limited practical value after GSSP-standardization (at least in global stratigraphic studies; in regional studies, however, it may still be important to distinguish between time and rock units).

Harland et al. (1989) states that, with time and rock deriving from the same standard reference point, "the two apparently distinct disciplines geochronology and chronostratigraphy will be different aspects of a single procedure". These authors suggest that the terms period, epoch, and stage shall be used for the different hier- archies of time-rock subunits in a GSSP-standardized scale. The terms period and epoch, they adopt from the traditionalgeochronologic scale, but for the next lower-in-rank time-rock unit, the geochronologic concept "age" is abandoned in favor of the chronostratigraphic concept "stage". The term "age" is dismissed in order to avoid ambiguity because of its general reference to time. However, if traditional geochronologic nomenclature, and including also the term "age", was used for the GSP-bounded time-rock subunits, the concept "Selandian Age" would refer to such a unit, whereas "Selandian Stage" could be used in a chronostratigraphic sense with reference to the historical stratotype sections. The double meaning of "age" is a minor problem (cf. "period" and "epoch" that refer also to time intervals in general) compared with introducing two stratigraphic meanings of the term "stage".

\section{References}

Cowie, J.W., Ziegler, W., Boucot, A.J., Bassett, M.G. \& Remane, J., 1986: Guidelines and statutes of the International Commission on Stratigraphy (ICS). Courier Forschungsinstitut Senckenberg 83, 1-14.

Harland, W.B., Armstrong, R.L, Cox, A.V., Craig, L.E., Smith, A.G. \& Smith, D.G., 1989: A Geologic Time Scale 1989. Cambridge Univ. Press. 263 pp.

B. Schmitz, Department of Marine Geology, Box 7064, University of Göteborg, S-402 32 Göteborg, Sweden. Fax: +46-31-7734903.

\title{
Paleocene sea-level fluctuations recorded in benthic foraminiferal assemblages from Gebel Oweina (Esna, Egypt): local, regional or global patterns?
}

\author{
ROBERT P. SPEIJER
}

The Egyptian Gebel Oweina section has previously been studied for biostratigraphical purposes by many authors (e.g. Nakkady 1950, 1957; Said \& Sabry 1964; El-Naggar 1966; Perch-Nielsen et al. 1978). Next to the paper by Charisi \& Schmitz (1994), this is the first documentation of its paleoenvironmental significance.

Benthic foraminiferal assemblages have been quantitatively analysed in order to obtain information on paleoenvironmental parameters during the Paleocene. In this paper I will focus on the paleobathymetric development.

A significant part of all benthic foraminiferal species encountered has been assigned to groups indicative of a certain maximum or minimum depositional paleodepth. This designation is based on data from Egypt (LeRoy 1953; Said \& Kenawy 1956; Luger 1985; Speijer in press), Tunisia (Berggren \& Aubert 1975; Aubert \& Berggren 1976; Saint-Marc \& Berggren 1988), compilation studies on deep-sea assemblages (Tjalsma \& Lohmann 1983; van Morkhoven et al. 1986) and personal observations on North African Paleocene benthic foraminiferal assemblages. Many species have been disregarded from these groupings due to their wide paleobathymetric distribution or due to taxonomical difficulties. The following groups were distinguished (only species encountered in Gebel Oweina are mentioned):

Group 1, inner-middle neritic (0-100 m) indicators: high abundances of Haplophragmoides excavatus, Frondicularia spp., Eponides cf. elevatus.

Group 2, outer neritic (100-200 m) indicators: high abundances and/or upper depth limits of Spiroplectammina spp., Gaudryina spp., Tritaxia spp., Dorothia spp., Cibicidoides spp., Gavelinella spp., Pullenia spp., Neoflabellina jarvisi, Marginulina tuberculata, Angulogerina cuneata, Hanzawaia cf. caribaea, Osangularia plummerae.

Group 3, deep outer neritic (150-200 m) indicators: high abundances and/or upper depthlimits of Coryphostomamidwayensis, Aragonia aragonensis, Globocassidulina subglobosa, Turrilina brevispira, Anomalinoides affinis, Gavelinella beccariiformis, Gavelinella susanaensis, Angulogavelinella avnimelechi.

Group 4, upper bathyal (200-600m) indicators: high abundances and/or upper depth limits of Spiroplectammina spectabilis, Nuttallides truempyi, Gyroidinoides globosus, Bulimina trinitatensis, Bulimina beaumonti, Alabamina creta, Nonion havanen- se, Pullenia coryelli.

This paleobathymetric ranking of different groups does not mean that depth itself is critical to distributional patterns. This ranking is merely the combined reflection of changes in water-mass properties, organic carbon flux to the seafloor, light penetration, water-column stability, substratum, etc. along a depth gradient. For this reason, the above-mentioned individual North African paleobathymetric ranges cannot be adopted straightforward to regions under very different environmental regimes (e.g. boreal areas).

In Gebel Oweina both species richness and relative abundance of groups 2 and 3 suggest a generally deep outer neritic (150$200 \mathrm{~m}$ ) position on the very gently northward dipping paleoshelf. The high proportion (mostly about $90 \%$ ) of planktic foraminifera agrees with this estimate. However, superimposed changes in paleodepth are clearly reflected, ranging from inner/ middle neritic ( $50 \mathrm{~m}$; upper $\mathrm{P} 3 \mathrm{a} / \mathrm{NP} 4)$ to upper bathyal (300 m; middle P4/NP8) conditions (Fig. 1). The former is indicated by the temporal flooding of species mentioned in group 1 , next to a reduced relative abundance of planktic foraminifera. Upper bathyal conditions are concluded from the 


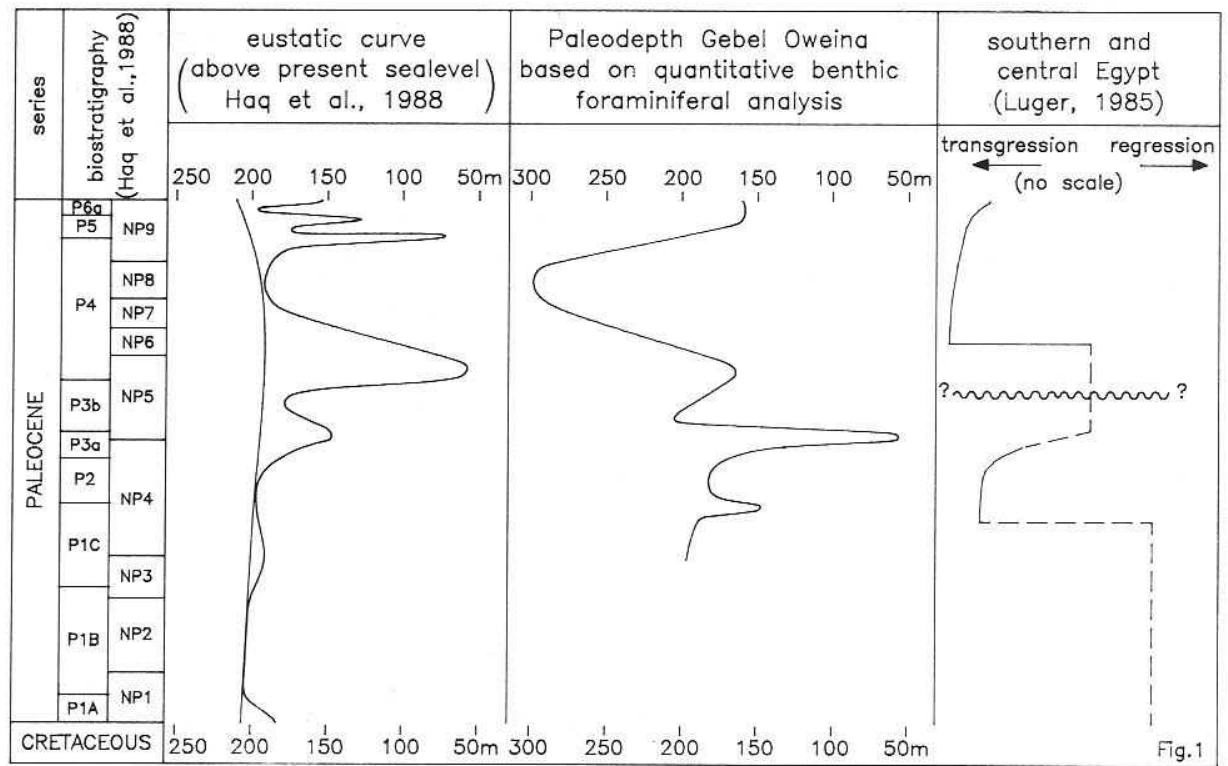

Fig. 1. Comparison of the paleobathymetric curve of Gebel Oweina with published sea-level curves.

temporal appearance of the bathyal markers of group 4.

The most interesting question is, whether the paleodepth curve is merely caused by very local uplift and subsidence, or if it is indicative of regional phenomena. A direct answer to this question can be found in a comparison with regional studies. It appears that the main paleodepth fluctuations in Gebel Oweina can also be traced in the Kharga-Aswan area (central and southern Egypt) as transgressive and regressive sequences (Fig. 1; Luger 1985, 1988). Luger's stratigraphical and paleontological study revealed a regression within $\mathrm{P} 3$ a resulting in a major hiatus (upper P3a to lower P4) and a subsequent transgression within $\mathrm{P} 4$ resulting in onlap of fine-grained basinal (middle neritic: $50-100 \mathrm{~m}$ ) sediments over marginal marine deltaic deposits. This late Paleocene transgression appears to have reached well into Sudan (Barazi \& Kuss 1987). Preliminary studies of benthic assemblages from the Kharga-Aswan area and from Wadi Qena confirm at least the main events of P3a shallowing, P4 deepening and upper P4/P5 shallowing. Thus, the central and southern part of Egypt experienced very similar relative sea-level fluctuations, pointing either at episodes of regional subsidence and uplift or at eustatic sea-level movements. To be able to distinguish between these two possibilities, similar paleobathymetric analyses should be conducted in other continental margin deposits.

A comparison with sea-level on- and offlap sequences in the North Sea Basin shows some interesting aspects. At the meeting of the Paleocene Working Group in Göteborg, E. Thomsen showed the presence of a regional unconformity, most probably due to sea-level fall, between the Danian and the Selandian stratotypes near the NP4-NP5 boundary (= within P3a). Furthermore, onlap of the Thanet Beds (Thanetian stratotype) in Kent started within NP6 and C26n (= lower P4) and maximum sea-level highstand is thought to have been reached within NP8 (= middle-upper P4), which was followed by subsequent erosional event due to a regression (Knox et al. in press). In a first approximation, these events in the North Sea Basin appear to coincide with the main events in Egypt. These events are also clearly shown in the eustatic curve by Haq et al. (1988), although they differ in magnitude (Fig. 1). However, since Paleocene paleontological correlation schemes are presently still being modified (W.A. Berggren, pers. comm.), and time resolution of these schemes is still rather low, it is still too early to conclude main eustatic events from these data. On the other hand, if these events eventually prove to be genuine, then they might appear to be strong tools for global correlation in continental margin deposits, especially when they are accompanied by evolutionary punctuations in one or more groups of the most common fossil planktic organisms (foraminifera, nannoplankton, dinoflagellates). With respect to the establishment of a GSSP for the DanianSelandian boundary, the (eustatic?) upper $\mathrm{P} 3 \mathrm{a} / \mathrm{NP} 4$ lowstand might be a very useful level. This level coincides with the major diversification of the nannoplankton genus
Fasciculithus (M.-P. Aubry, pers. comm.). Such a concept for this boundary would have the advantage of still being situated at the unconformity between the Danian and the Selandian stratotypes in the type area in Denmark. Localities containing outer neritic to upper bathyal deposits like Gebel Oweina are the best candidates for a GSSP based on these criteria. These are the most likely to have preserved a lowstand signal without major erosion, although extreme caution should be regarded in addressing their stratigraphic completeness.

\section{References}

Aubert, J. \& Berggren, W.A., 1976: Paleocene benthic foraminiferal biostratigraphy and paleoecology of Tunisia. Bulletin du Centre de Rechèrche PauSNPA 10, 379-469.

Barazi, N. \& Kuss, J., 1987: Southernmost outcrops of marine Lower Tertiary carbonate rocks in NEAfrica (Gebel Abyad, Sudan). Geologische Rundschau 76, 529-537.

Berggren, W.A. \& Aubert, J., 1975: Paleocene benthonic foraminiferal biostratigraphy, paleobiogeography and paleoecology of Atlantic-Tethyan regions: Midway-type fauna. Palaeogeography, Palaeoclimatology, Palaeoecology 18, 73-192.

Charisi, S.D. \& Schmitz, B., 1994: Stable isotope $\left(\delta^{13} C\right.$, $\delta^{18} \mathrm{O}$ ) records across the Paleocene section at Gebel Oweina, Egypt. GFF 116, 48-49.

El-Naggar, Z.R., 1966: Stratigraphy and planktonic foraminifera of the Upper Cretaceous-Lower Tertiary succession in the Esna-Idfu region, Nile Valley, Egypt, U.A.R. Bulletin of the British Museum (Natural History) Geology, Supplement 2, 1-291.

Haq, B.L, Hardenbol, J. \& Vail, P.R., 1988: Mesozoic and Cenozoic chronostratigraphy and cycles of sea level change. In C.K. Wilgus \& B.S. Hastings, H. Posamentier, J. Van Wagoner, C.A. Ross \& C.G. St. C. Kendall (eds.): Sea Level Changes: An Integrated Approach, 71-108. Society of Economic Paleontologists and Mineralogists, Special Publication 42.

Knox, R.W.O'B., Hine, N.M. \& Ali, J.R., in press: New information on the age and sequence stratigraphy of the type Thanetian of Southeast England. Newsletters on Stratigraphy.

LeRoy,L.W., 1953: Biostratigraphy of the Maqfi section, Egypt. Geological Society of America, Memoir 54, 1-73.

Luger, P., 1985: Stratigraphie der marinen Oberkreide und des Alttertiärs im südwestlichen ObernilBecken (SW-Ägypten) unter besonderer Berücksichtigung der Mikropaläontologie, Palökologie und Paläogeographie. Berliner Geowissenschaftliche Abhandlungen, Reihe A 63, 1-151.

Luger, P., 1988: Maastrichtian to Paleocene facies evolution and the Cretaceous/Tertiary boundary in middle and southern Egypt. Revista Española de Paleontologia, $n^{\circ}$. Extraordinario, Palaeontology and evolution. Extinction Events, 83-90.

van Morkhoven, F.P.C.M., Berggren, W.A. \& Edwards, A.S., 1986: Cenozoic cosmopolitan deepwater benthic Foraminifera. Bulletin des Centres de Recherches Exploration-Production Elf-Aquitaine, Memoir 11, 1-421.

Nakkady, S.E., 1950: A new foraminiferal fauna from the Esna shales and Upper Cretaceous chalk of Egypt. Journal of Paleontology 24, 675-692.

Nakkady, S.E., 1957: Biostratigraphy and inter-regional correlation of the Upper Senonian and Lower Paleocene of Egypt. Journal of Paleontology 31, 428-447.

Perch-Nielsen, K., Sadek, A., Barakat, M.G. \& Teleb, F., 1978: Late Cretaceous and Early Tertiary Calcareous nannofossil and Planktonic foraminifera zones from Egypt. (Actes du VI Colloque Africain 
de Micropaleontologie - Tunis 1974.) Annales des Mines et de la Geologie 28, $337-403$.

Said, R., \& Kenawy, A., 1956: Upper Cretaceous and Lower Tertiary foraminifera from northern Sinai, Egypt. Micropaleontology 2, 105-173.

Said, R. \& Sabry, H., 1964: Planktonic foraminifera from the type locality of the Esna Shale in Egypt. Micropaleontology 10, 375-395.

Saint-Marc, P. \& Berggren, W.A., 1988: A quantative analysis of Paleocene benthic foraminiferal assemblages in central Tunisia.Journal of Foraminiferal Research 18, 97-113.

Speijer, R.P., in press: The late Paleocene benthic foraminiferal extinction as observed in the Middle-East. Bulletin de la Société Belge de Géologie, Special Issue: Paleocene-Eocene boundary events.

Tjalsma, R.C. \& Lohmann, G.P., 1983: Paleocene-Eocene bathyal and abyssal benthic foraminifera from the Atlantic Ocean. Micropaleontology, Special Publication 4, 1-90.

Robert P. Speijer, Department of Geology, Faculty of Earth Sciences, Utrecht University, Budapestlaan 4, 3508 TA Utrecht, The Netherlands. Fax +31-30-535030.

\section{The velascoensis event in Egypt: paleogeography and biostratigraphic implications}

\section{AMIN STROUGO}

Notable changes in the patterns of sedimentation in late Paleocene times have been documented from various localities of Egypt in recent years. The event that produced those changes is believed to be primarily tectonic (Strougo 1986), coupled with a global sealevel highstand (Haq et al. 1988). This was marked by accentuation of uplift of the Mediterranean coast, with emergence and erosion of several positive structures and increased subsidence in the internal depocenters. In the north and west, old positive structures were reactivated and gave rise to prominent submarine features or elevated islands. The Gebel Ataqa block, a prominent positive feature at that time, linked up in the west with the Abu Roash, Khatatba, and Qattaniya Uplifts to form what is known as the Suez-Cairo-Qattaniya High (Said 1990). In the Gulf of Suez region, the two Galalas and Wadi Araba, which cuts between them, formed one structural block, the Wadi Araba High. In brief, the partial isolation from the Tethys of extensive tracts in central and southern Egypt was achieved at the dawn of the Paleocene.

Upwarping and block faulting characterize this episode of tectonic activity and affected significantly the regional depositional framework. In the uplifted areas (e.g. Abu Tartur Plateau, Abu Mingar, Bahariya-Farafra divide, Gebel Thelmet, etc.) the sediments are thin and made up of bioclastic material, bioconstructed masses, or cross-bedded calcarenites. In the down-faulted blocks (e.g. Abu Roash, N scarp of Northern Galala Plateau, Saint Paul, Wadi El Dakhl, etc.) the sediments often include slumps, debris flows and other gravity-induced features reflecting transport along conspicuous slopes. Even in more basinal settings, the tectonic instability of the sea floor is attested by coquinal stringers, foraminiferal packstones or shell lags within an otherwise thick sequence of pelagic shale or chalk. Finally, in late Paleocene time the sea reached its maximum extension towards the south. Broad areas in central and southern Egypt subsided and, for the first time, shelfal sediments extended as far south as the Abyad Plateau in northern Sudan (Barazi 1985). The area to the southwest of Aswan (KurkurDungul area) was flooded by a very shallow sea harboring a vast array of macroinvertebrates for which a special division was created - the Kurkur-Stufe or Kurkurian Stage (Blanckenhorn 1900).

As a consequence of the velascoensis event, the discrimination between the Planorotalites pseudomenardii Zone and the Morozovella velascoensis Zone is often difficult, particularly in the tectonically disturbed areas. Reworked microfossils and exotic megaclasts have been repeatedly found in this interval during the past few years. Minor hiatuses may go unrecorded in terms of planktonic foraminifers, but may be detected by calcareous nannofossils, as the biostratigraphic resolution of this group is higher in this interval.

\section{References}

Barazi, N., 1980: Sedimentologie und Stratigraphie des Abyad Beckens (NW Sudan). Berliner Geowissenschaftliche Abhandlung 64A, 1-86.

Blanckenhorn, M., 1900: Neues zur Geologie und Paläontologie Ägyptens. II Das Palaeogen. Zeitschrift der Deutschen Geologischen Gesellschaft 52, 403479.

Haq, B.L, Hardenbol, J. \& Vail, P.R., 1988: Mesozoic and Cenozoic chronostratigraphy and cycles of sea level change. In C.K. Wilgus \& B.S. Hastings, H Posamentier, J. Van Wagoner, C.A. Ross \& C.G. St. C. Kendall (eds.): Sea Level Changes: An Integrated Approach, 71-108. Society of Economic Paleontologists and Mineralogists, Special Publication 42.

Said, R., 1990: Cenozoic.In R. Said(ed.): The Geology of Egypt, 451-486. Balkema. Strougo, A., 1986: The velascoensis event: a significant episode of tectonic activity in the Egyptian Paleogene. Neues. Jahrbuch für Geologie und Paläontologie, Abhandlung 173, 253-269.

Amin Strougo, Ain Shams University, Faculty of Science, Department of Geology, Abbassia, Cairo, Egypt.

\section{Calcareous nannofossil stratigraphy across the Danian-Selandian boundary in Denmark}

\section{ERIK THOMSEN}

Denmark holds the type areas of both the Danian and the Selandian stages (Thomsen 1981; Perch-Nielsen \& Hansen 1981). Both were erected on the basis of stratigraphic investigations of sections in eastern Denmark. The Danian deposits consist of limestone and chalk, often very fossiliferous. The deposits are all included in the Danskekalk Formation (Fig. 1). The Selandian deposits are mainly siliciclastic. Four formations have been recognized; the Lellinge
Greensand, the Kerteminde Marl, an unnamed grey clay unit, and the Holmehus Fm (Heilmann-Clausen 1989). The Lellinge Greensand forms the conglomeratic basal unit of the Selandian deposits (Perch-Nielsen \& Hansen 1981). The Lellinge Greensand and the Kerteminde Marl are strongly calcareous and contain calcareous nannofossils; the others are noncalcareous.

The Danian-Selandian boundary is generally considered to be 